\title{
Syariah Criminal Code (II) Enactment 1993 Amendment 2015: Can Kelantan Enforce Hudud?
}

\author{
Mohamed Azam Mohamed Adil *
}

On $26^{\text {th }}$ May 2016, an unprecedented move occurred in Malaysia's Parliament. The president of PAS, Abdul Hadi Awang, proposed a private bill meant to amend section 2 of Syariah Court (Criminal Jurisdiction) 1965 (Amendment 1984) - also known as RUU 355. His amendment was designed to increase the present criminal jurisdiction of the Syariah Courts, currently limited to a fine not exceeding five thousand ringgit or imprisonment for a term not exceeding three years or to whipping not exceeding six strokes, or to any combination thereof.

Earlier, on $19^{\text {th }}$ March 2015, the Kelantan State Assembly passed an amendment to the Syariah Criminal Code (II) 1993 (hereinafter referred to as the '1993 Enactment'). Several key provisions in the enactment were improved and revised.

Under Kelantan's 2015 Amendment, the provision that provided non-Muslims with the option of being tried under the 1993 Enactment was abolished. Under the new 2015 Amendment, the 1993 Enactment was also restricted to Muslims over 18 years of age. Consequently, Islamic criminal law cannot be imposed on either non-Muslims or Muslims below the age of 18. This is in line with the Ninth Schedule of the Federal Constitution, List II-State List, which affirms that Syariah offenses can only be imposed on legally responsible Muslims.

Other amendments to the enactment concern hudud punishments. For example, in the case of theft, regulations and prerequisites for hudud punishments were revised, improved and streamlined. In this regard, a thief with one hand is now exempted from losing their other hand. Moreover, if they gain the right to the property they stole before judgement is passed, they will be exempted from the hudud punishment altogether-although not necessarily from other charges under ta'zir. Another addition to the theft punishment is the sequence of punishments for theft: amputation of the right hand at the wrist for the first offense, amputation of the left foot for the second offense, and imprisonment up to 15 years for the third (and any subsequent) offenses.

In the case of adultery and sodomy, the new amendment is subjected to syahadah (testimony) and high requirements of bayyinah (evidence), or 'burden of proof'. Under Section 46 (2) of the 1993 Enactment, the pregnancy of an unmarried woman was considered proof of fornication. In such circumstances, the woman would be liable to be punished to the full extent of the law (100 lashes for an unmarried woman or stoning to death for a married woman) unless she 
could bring forward evidence that proved her innocence. Provisions similar to this, however, have led to many rape victims being unjustly punished in countries like Pakistan and Afghanistan (under the Taliban). As a result, under the new 2015 amendment, Section 46 (2) was repealed. This was done by incorporating public opinion on this matter, and by considering the multiple views of relevant parties.

Another notable addition by the 2015 Amendment was the inclusion of sodomy under the jurisdiction of ta'zir. Previously, Section 16 of the 1993 Enactment had only offered an exception to husbands committing sodomy with their wives.

From the perspective of classical Islamic jurisprudence, three of the four major mazhabs (Maliki, Syafi'i and Hanbali) consider sodomy between males as zina (illicit sex) and therefore subject to the hudud punishment. Only the Hanafis have placed it under the purview of ta'zir; because they define zina as 'unlawful vaginal penetration between unmarried man and woman' they distinguish it from sodomy, which they define as 'anal penetration, which may include the wife or involve another male'. Due to this distinction, the Hanafis categorise sodomy as ta'zir instead of hadd/hudud.

From the Malaysian legal perspective, sodomy is unlawful across both the Penal Code and the respective Syariah Criminal Enactments of the various States. For instance, Section 25 of the Syariah Criminal Offences (Federal Territory) Act 1997- hereinafter referred to simply as 'Act 1997'—provides that "Any male person who committed sodomy (liwat) shall be guilty of an offence. They are liable to a fine not exceeding five thousand ringgit or imprisonment for a term not exceeding three years or to a whipping not exceeding six strokes or to any combination thereof."

Section 377A of the Penal Code provides that "Any person who has sexual connection with another person by the introduction of the penis into the anus or mouth of the other person is said to commit carnal intercourse against the order of nature," and which will entail a 20-year jail sentence and whipping if convicted (section 377B).

Both of these provisions are deemed constitutional by the Malaysian courts. In the case of Sukma Darmawan Sasmitaat Madja v Director General of Prisons Malaysia \& Another 2 MLJ 241, the Federal Court ruled that both courts have jurisdiction to hear cases involving sodomy. However, when comparing the two provisions, it appears that the sentence imposed by the Penal Code is heavier than the 'hudud' punishments of Act 1997.

The 2015 Amendment also abolished several provisions of sex offences, such as sex between women (musahaqah), necrophilia (ityan al-mayyitah) and bestiality (ityan al-bahimah). Under the 1993 Enactment, these offenses were 
punishable by ta'zir. But in spite of the 2015 Amendment, some quarters within the state government have stated that the aforementioned unlawful actions should be placed under the category of sodomy or liwat. That categorisation, however, holds little ground because it is based on a vague definition of sodomy - especially when it is considered that lesbian sex, bestiality (sexual intercourse with animals) and necrophilia (sexual intercourse with corpses) are all very distinctive acts. The author, however, is inclined to the position that these sexual offenses under section 19-21 of the 1993 Enactment should be retained, rather than abolished.

Looking at the provisions under the Penal Code, the punishment for bestiality is a 20-year prison sentence, a fine, and may also include whipping (Section 377). These punishments are also applied to sodomy and oral sex offenses - both considered obscenities. As for other sex-related offenses, including the public display of sexual and lewd acts, the punishment is two years imprisonment.

\section{Can the Kelantan Government Implement the 1993 Enactment (Amendment 2015)?}

The implementation of hudud in Kelantan would require in depth and careful deliberation. Current realities in Kelantan and Malaysia have to be taken into consideration. Moreover, despite the fact that the bill has been passed by the Kelantan state government, the hudud bill cannot be legally implemented without the approval of the Federal Government. Besides these legal issues, the implementation of hudud requires wisdom; all aspects of the bill must be predicated upon credible Islamic scholarship.

Although hudud punishments should not discriminate on the grounds of skin colour or religious affiliation when upholding justice, the gap between theory and practice remains a challenge. To resolve this, a thorough understanding of the Islamic concept of awlawiyyat (priorities) and the principles of Siyasah Syar'iyyah should act as sources of guidance and implementation. In the context of Malaysia's current socio-political realities, moral offenses like adultery, sodomy and musahaqah, which fall under the State Syariah Criminal Enactments, apply to Muslims only. Non-Muslims should be excluded, and despite a view that doing so would contradict Article 8 (1) of the Federal Constitution concerning 'equality before the law'.

Amendments to the Constitution, to existing provisions in the Penal Code, and to the Syariah Criminal Law of the States, all of which involve federal and state jurisdiction, should be revisited. Certain hudud punishments (including stoning to death and 100 lashes) are beyond the jurisdiction of the Syariah Courts (Criminal Jurisdiction) Act 1965 (Amendment 1984). Moreover, the Parliamentthrough the Federal Constitution - has the ability to specify the legal boundaries 
of the Syariah Courts. The Ninth Schedule, Item 1, List II-State List, limited the criminal jurisdiction of the Syariah Courts to Muslims only and, in addition, restricted offences to those that go against the teachings of Islam. The State List also gave powers to the Syariah Courts to determine the appropriate penalties for such offenses (as long as they did not overstep the Civil Laws).

In regards to hudud, it is a common Western misconception that Islamic criminal law is unjust, severe, and inhumane, especially when compared to modern human rights. Although it is not the author's aim to refute these claims here, suffice it to say that the core principles of hudud are 'prevention' and 'education'. Islamic jurists believe that the severe penalties imposed on offenders by the hudud are appropriate in that they serve to prevent further criminal acts via deterrence, while also educating both the offenders and the general public. Furthermore, the severe sentences come with strict requirements. For instance, any evidence or testimony collected must not exhibit doubt. In this regard, the Prophet Muhammad said: "reject hudud if there was an element of doubt in it because a mistake in forgiveness (clemency) is better than sentencing in error."

Taking into account the constraints of the Federal Constitution, the Penal Code, and the pluralist sociopolitical realities of Malaysia, implementing hudud punishments is only feasible among Muslims, as those who are already under the purview of the Syariah Courts. In order to expand the scope of the Syariah Courts, however, the Syariah Court (Criminal Jurisdiction) Act 1965 (Amendment 1984) must be amended by Parliament through a simple majority. This prerogative of Parliament is clearly spelled out in Article 76A (1) of the Federal Constitution. Otherwise, no state government can enforce the 1993 Enactment (Amendment 2015).

In conclusion, although the 1993 Enactment (Amendment 2015) has gained the consent of the Sultan of Kelantan, the hudud bill cannot be enforced without the consent of Parliament. It is appropriate, therefore, to say that 'the ball is now in the Parliament's court'. In order for the hudud bill to be implemented in Kelantan, it must be passed with a simple majority. If it is not approved, the recent 2015 Amendment, despite being passed by the state of Kelantan, will be ineffective and susceptible to the same fate as the 1993 Enactment.

\section{Notes}

* Mohamed Azam Mohamed Adil is Deputy Chief Executive Officer, International Institute of Advanced Islamic Studies (IAIS) Malaysia/Assoc. Prof., Academy of Contemporary Islamic Studies (ACIS), Universiti Teknologi MARA, Shah Alam. 